\title{
Sociology of science: are knowledge production and the quest for scientific status two divergent courses?
}

\section{Sociologia da ciência: a produção de conhecimento e a busca por status acadêmico são caminhos divergentes?}

Martin Lindsey Christoffersen

Professor do Centro de Ciências Exatas e da Natureza Universidade Federal da Paraíba Cidade Universitária

58051-900 - João Pessoa - PB - Brazil mlchrist@dse.ufpb.br

Waltécio de Oliveira Almeida

Professor do Centro de Ciências Biológicas e da Saúde Universidade Regional do Cariri Rua Cel. Antônio Luiz 1161 63100-000 - Crato - CE - Brazil walmeida@urca.br

Tassos Lycurgo

Professor do Centro de Ciências Humanas Letras e Artes Universidade Federal do Rio Grande do Norte Cidade Universitária 59000-000 - Natal - RN - Brazil. tl@ufrnet.br

Recebido para publicação em julho de 2008. Aprovado para publicação em janeiro de 2009.

CHRISTOFFERSEN, Martin Lindsey; ALMEIDA, Waltécio de Oliveira; LYCURGO, Tassos. Sociology of science: are knowledge production and the quest for scientific status two divergent courses?. História, Ciências, Saúde Manguinhos, Rio de Janeiro, v.16, n.2, abr.-jun. 2009, p.505-513.

\section{Abstract}

With the publication of a cover article in Nature by a group of Brazilian researchers, it has been suggested that science in Brazil has "progressed" to a level comparable to that of more developed countries. We argue that Brazil's contribution to the world scientific circuit is otherwise not very significant, even if more biological journals are published there than in other countries of continental dimensions, such as Australia, Canada and Russia.

Keywords: sociology of science; publications; citations; Brazil.

\section{Resumo}

Com a publicação de um artigo de capa na Nature por um grupo de pesquisadores brasileiros, foi propagado que a ciência no Brasil tem progredido a um nível comparável ao de países desenvolvidos. Argumentamos que as contribuições do Brasil para o circuito científico internacional não são expressivas, mesmo que mais revistas biológicas sejam publicadas no Brasil do que em outros países continentais, como Austrália, Canadá e Rússia.

Palavras-chave: sociologia da ciência; publicações; citações; Brasil. 
$\mathrm{I}_{\mathrm{i}}^{\mathrm{n}}$ n this article, we consider the constraints on information and knowledge production inherent to developing countries and the competitive process by which scientific status is attained. We note that when compared to other major countries, Brazil has a smaller number of international publications and fewer citations in internationally indexed periodicals. Both these measures, however, only represent quantitative assessments of information production and its relative impact.

Though these measures may be useful for building up a picture of how science actually works, we would argue that they are incapable of providing a qualitative assessment of creative (Gardner, 1996) and revolutionary science (Kuhn, 1962). Information and its impacts of themselves neither produce nor measure knowledge or wisdom. From this perspective, one-off success in the field of genetics may represent the tip of the iceberg.

In the sciences or other areas of knowledge production, the prestige of a researcher is usually gauged by the number of papers $\mathrm{s} /$ he has published in periodicals of a high standing or how many citations these papers receive. The latter index, which measures the impact factor on the scientific community, is often considered more representative than merely counting publications (Garfield, 1971). These data can easily be obtained from online international indexes, such as the Science Citation Index and Social Sciences Citation Index.

The former Institute of Scientific Information (ISI) nowadays belongs to the Thomsom Reuters, a private North American corporation that maintains the largest current database on international publications from all areas of knowledge. Many Brazilian institutions have access to this database over the Internet (http://apps.isiknowledge.com/WOS) It contains almost forty million international scientific publications dating back to 1945 . Once every seven days, between around twenty and seventy thousand new references are added.

But what valid correlation can be established between the number of papers published or their citation impact and the knowledge produced thereby? In other words, is it possible to correlate a quantitative assessment with an evaluation of creative insight and quality of work? Is there a mathematical correlation between scientific merit and citation impact, or can the sociology of science point to other relevant factors? Measuring the impact factor of scientific production and even conferring Nobel prizes in the sciences is, in our view, much akin to measuring the most popular TV programs, producing best-selling books and announcing the Oscars to members of the film industry. All these indexes no doubt measure relative impact on their respective consumers.

However, it still seems intuitively obvious that there must be a large distance between the best-selling books, most watched TV programs and movies and most useful scientific information on the one hand, and the best literature, best quality films and most creative scientific production on the other. In the sciences in particular, citation can be dependent on many variables other than scientific merit: an author's reputation, a controversial subject matter, circulation of the journal, availability and extent of library holdings, dissemination of reprints, coverage by secondary indexing and abstracting services and allocation of research funds (Aaronson, 1975). In other words, information produces neither knowledge nor wisdom (Garfield, 1973a). At the risk of being accused of preferring 
the world of subjectivity (Garfield, 1973b), we strongly oppose using citation indexing as a valid measure for evaluating and comparing scientific merit (Garfield, 1970) or as the basis for measuring the quality of research (Aaronson, 1975). These reflections may help to inform the present state of science in Brazil, which appears to us somewhat paradoxical.

We have reached the end of the "lost decade of science and technology" in Brazil (Sardenberg, 2000). The country's public institutions are undergoing a worsening crisis of an unprecedented scale in their recent history. In this context, a group of Brazilian researchers financed by Fundação de Amparo à Pesquisa do Estado de São Paulo (Fapesp; São Paulo State Foundation for the Furtherance of Research) gained prominence on the cover of the June 2000 edition of Nature (Simpson et al., 2000). In its 131-year existence, never had an article by a Brazilian research group graced the cover of this periodical. Their scientific breakthrough: the complete sequencing of the genome of the bacteria Xylella fastidiosa, which causes disease in citric fruits. Not only was this the first fully-sequenced plant pathogen in the world, but a variety of this microorganism is a major blight on orange plantations in California. The United States government has already contracted the Brazilian team to develop further study into the genetic sequences of the American variety. A second piece of news which runs counter to the most pessimistic expectations is that there are 27 articles by a total of 104 Brazilian authors on the ISI electronic database that have been cited more than fifty times since 1990. Note that the actual number of citations ranges from 58 to 258 Finally, it is a fact that scientific production has increased in Brazil, growing from around half a percent of the world's indexed scientific production to just over one percent in the last decade.

What this promising news fails to convey, however, is the major regional disparity amongst the research conditions across the country. Indeed, it could be argued that this domestic inequality is like a scaled-down version of the well-documented global disparity between developed and developing nations. In a country with extreme social contrasts, the scientific panorama is no exception. The vast majority of country's "islands of competence" (Oliveira, 1985) are located in the south-eastern and southern regions of the country. There is no consistent nationwide investment in research beyond a few recognized groups of excellence, with the noteworthy exception of the grants provided by the Conselho Nacional de Desenvolvimento Científico e Tecnológico (CNPq; Ministry of Science and Technology Council for Technological and Scientific Development) and the Coordenação e Aperfeiçoamento de Pessoal de Nível Superior (Capes; Ministry of Education Agency for the Development of Research in Higher Education). Peripheral institutions in the country have come to depend exclusively on electronic databases to sustain their scientific output. Under these conditions, it becomes difficult even to talk about a truly national science.

So what can we conclude from the reports we read in the local press that science in Brazil has finally reached the threshold of the science practised in developed nations? Certainly, the country has progressed scientifically. For example, Brazilian zoology has gone through three paradigm shifts and there are signs that the country is acquiring maturity and independence from the scientific institutions located abroad (Zarur, 1994). But what does this apparent progress truly represent? 


\section{Scientific change}

Science aims at producing new knowledge, always questioning available knowledge in the light of new data and theories. The doctrine of scientific progress is a controversial subject, but it is fair to state that one way in which science progresses is that it gradually moves towards a predefined goal (Barnett, Fuller, 1998). In another sense, science is also believed by many to advance in revolutionary bouts, when previous paradigms are apparently superseded by more recent paradigms (Kuhn, 1962). Strange new ideas are sometimes accepted and gain popularity, particularly if they appear to have a greater explanatory power and can be applied to a larger body of data than their predecessors. These changes are described as revolutionary because they occur only occasionally or in cycles, being interspersed by periods of normal science in which ideas that were previously considered marginal are brought into the scientific establishment.

In biology, for example, Linnaeus introduced a system for naming the known biodiversity in 1758; Lamarck proposed explicitly evolutionary ideas in 1802; Darwin established natural selection as a mechanism to explain evolution in 1859; the genetic theory of heredity based on the acceptance of Mendel's laws was established in 1900; and the double helix of the DNA molecule was described in 1953. These short cycles do not, however, indicate that all scientific players immediately acknowledge the value of the new theories. As Max Planck, winner of the 1918 Nobel prize in physics, notoriously explained, theories end up being established because a whole generation of scientific opponents eventually reach the end of their careers or die after about fifty years of scientific activity and the new generation that steps into their shoes simply becomes familiar with the best theories left by the past generation (Salzano, 2000).

As examples of longer cycles, we may cite the Cartesian period (which is coming to an end after about three hundred years) (Horgan, 1997), and the essentialist philosophy of Aristotle, which survived over a thousand years before being surpassed by the transformationist vision resulting from $19^{\text {th }}$ century evolutionary theory.

\section{Scientific recognition and the 'selection of ideas'}

Evaluating the situation described above, we may speculate that in science, truly creative and revolutionary ideas are only recognized several years or decades after they are first formulated or published. For example, more than thirty years passed before the acceptance of Mendel's proposals, while almost twenty years were necessary for Freud's ideas to be established. Even with apparent exceptions to this rule, such as Darwin and Einstein, who harvested some of the glory of their discoveries in their lifetimes, we usually observe prolonged gestation periods for the maturing of successful ideas before they are exposed to the public.

One of the hurdles to obtaining credit for new theories is that they have to go through a long period of rigorous testing. Such is the evaluation of Popper (1976) and Hull (1997), both of whom proposed that the sciences evolve in a way that is analogous to biological species. As in populations, which originate in demes and may expand or retract in future generations, these authors describe the process of natural selection that seems to determine 
the fate of scientists, research groups and scientific ideas. This description applies very well to the process of normal science; that is, it tells us a great deal about how science (and scientists) actually work (Maienschein, 2000). But this characterization of science would not seem to adequately prescribe the mechanisms and the postures and preconditions required for the production of revolutionary science.

The sociology of science testifies that creative ideas, revolutionary outlooks and totally new points of view are not the privilege of particular cultures or institutions. On the contrary, individuals working in locations that are marginal to the centers of scientific power, distant from the more traditional and renowned institutions, different from the dominant culture, are more inclined to view the world from a different perspective and thus to contribute with new and creative theories for science. Gardner (1996), studying human creativity, concluded that the most creative individuals usually work alone and are less comfortable with social interaction. He also noted that great names in our history usually gain fame for a single great discovery in their lives. This is not surprising if we consider that leadership in a field requires at least ten years' intensive research before a theory can be proposed that may change the course of humanity (Gardner, 1996).

Meanwhile, established scientific institutions are not generally predisposed to acknowledging the merit of minority ideas, which means that such ideas tend to be repeatedly ignored whenever they contradict the consensus. In science it is therefore not enough to have new and creative ideas; a good dose of controversy is necessary for such deviant theories to survive in an environment that is hostile to change. Only a very few novel scientific theories, like genetic mutation, have managed to take root in scientific communities and be established by the next generations. The prestige of the author may help; the timeliness of the announcement of a new theory and the vehicles through which this is done may count; but the success or rejection of scientific propositions generally depends on a large pool of stochastic events, of which content and impact are only two of many factors. The 'rediscovery' of previous scientific ideas is usually a highly subjective process (Sapp, 1990). Discovery also represents a process of social recognition. A theory of discovery should concern itself not with determining what makes discoveries happen, but with what makes certain happenings discoveries (Brannigan, 1979). What retrospectively counts as "good science" may often originate from priority disputes among scientists, 'whiggish' accounts of the history of science; that is, accounts of the winners in historical controversies serving the personal interests of the researcher, and epistemic convictions that dictate what will count as acceptable practice and how theory and practice should work together to yield scientific knowledge (Maienschein, 2000).

\section{Indexing agencies: status vs. democratic change}

Far from representing all that is published in science, the references indexed by the ISI only represent the production from a selected pool of international journals upon which the status of respectability has already been conferred by the international scientific community according to the criteria of visibility, periodicity, regularity, language, extent of indexing by international reference vehicles, circulation range and place of publication. 
It is therefore logical to conclude that there is ferocious competition for prestige among scientific publications, of which only a few achieve international visibility and respectability. It is in this way that scientific institutions (journals, textbooks) may act to block conceptual change (Grantham, 1999). Disciplinary specialties and scientific societies also function effectively as gatekeepers of scientific norms and practices. The power of the institutions to which researchers are affiliated and the cultural characteristics of the society in which they perform also control individuals and their production of ideas. One powerful control system in science is the refereeing process by scientific peers. The incoherence of this mechanism for the production of revolutionary science is that scientists with radical ideas do not by definition have peers. When their ideas diverge strongly from those of their colleagues they will tend to be rejected before publication. When these ideas come from marginal locations, where the scientists may not excel in the dominant language, accepted writing skills, prevailing cultural norms, etc., their chances of reaching print in high status journals become dim, even if their papers contain important new perspectives.

It starts to become clear, then, that the scientist's daily grind is a constant conflict between reason, arguments and evidence on the one hand, and against power, prestige and politics on the other. It appears to us that the scientific ideal of creativity and revolutionary change in knowledge is effectively blocked and controlled by the social institutions of science. Each individual scientist must choose his posture from a gradient of options ranging from mass production of standard normal science, which in some instances is quickly approved and applauded by scientific societies and duly propagated by prestigious journals, to solitary work outside the establishment and against the established consensus in the hope of gaining the tardy or posthumous recognition of society at large through sheer obstinacy and conviction in his/her ideas. The option for revolutionary science is the true path by which science can advance on a larger scale, but it can demand almost unbearable sacrifices on the part of the scientist in terms of his/her image in relation to his peers, budget cuts and social exclusion.

The marginal position of science produced in Brazil is thus not simply a consequence of lack of financial investment. Almost nothing that is published in developing nations appears in the ISI, and what is published rarely represents revolutionary knowledge with the potential to change the future of science. Whatever does occasionally make its way into the international indexes often represents what the holders of scientific power deem to be most in their interests. For example, from the developing world the gatekeepers of science will tacitly admit the publication of descriptive work, the study of regional problems with clear global implications, or the replication of experiments, techniques, research programs and methods originally developed in the world in effective control. On the other hand, contestations of knowledge produced at the hub of power will be regarded with suspicion and effectively blocked when they do not follow the sanctioned formulae.

The challenge for developing nations is how to both publish and become recognized for work that effectively contests the status quo. Science is presently a product of the industrialized countries. It is controlled by established scientists and represents the usufruct of developed nations. Like all human organizations, scientific societies are political entities, veritable class associations, which lay down the rules, elect their idols, and above all help exclude all those who might rock the boat. 


\section{Number of publications and scientific status}

The growth in the number of scientific publications is a direct function of industrial development and mass communication. To demonstrate this we may take as an example the work of Reish (1958) on the systematic literature between 1758 and 1954. His results indicate a constant increase, albeit with a few short periods of decline (e.g. during the first and second world wars). Between 1909 and 1939, the number of systematic papers rose by $110 \%$, while the number of articles on chemistry quadrupled and those on geology doubled in the same period.

This phenomenon has parallels with industrial politics (De Masi, 2000). Under the sway of the popular American slogan "publish or perish" and of the more recent "be cited or be damned" (Garfield, 1971), any researcher can become a machine for churning out scientific papers. In our Information Era, the recipe for gaining gradual prestige and power in science seems to be: (a) publish short papers (2-10 published pages) containing a general statement of the problem to be addressed and politically correct citations, following established formulae for success and introducing only small and gradual changes; (b) subdivide a work into as many papers as possible (the increasingly conspicuous syndrome of 'salami science'); (c) give precedence to methodological problems or subjects of general interest which stand a chance of being read and cited by a larger number of people; (d) produce papers in teams, in which each author puts his name on all the papers produced by his lab colleagues and vice-versa (an effective concrete example of "you scratch my back, I'll scratch yours,"); and, whenever possible, (e) choose specialties that affect the largest number of researchers possible so there will be a broader potential readership for your papers.

One example of deserved publication success is Eugene Garfield, who wrote a weekly column in Current Contents and is one of the most prolific authors on the ISI database, with 1491 publications. This represents over thirty papers published every year over almost fifty years, or more than one paper published every week during the thirty most productive years. Any scientist from a marginal scientific environment cannot help but envy the rare privilege of having almost everything produced in a lifetime duly published and indexed in the ISI database.

\section{Concluding remarks: Brazil on the cover of Nature}

We correlate the number of published papers and number of citations in the international indexes not with scientific progress, but with the competitive quest for personal status, one of the most efficient stimuli for scientific enterprise. Other authors have expressed similar opinions (Cunha, 1990; Saiz-Salinas, 1996; Prolla, 2000). Our theoretical and social formulations presented herein force us to abandon any fleeting illusion that our scientific ideas will be immediately recognized or promptly accepted by the international establishment. To paraphrase Ghiselin (2000, p.375), we agree that "in a hierarchical society based on privilege rather than merit, one gets a system that is characterized as organized bad manners." Consequently, in order to participate in an effectively international science, we depend primarily on the quest for truly democratic 
scientific enterprise. Such a novel perspective seems already to be in the making. It is derived from systems theory and is based on the non-competitive juxtaposition of ideas from a diversity of individuals. The non-competitive combination of diverse experiences enhances the performance of the system as a whole (Johnson, 2000). Humans have a limited problem-solving capacity, and groups tend to outperform individuals in solving difficult problems. The next revolution in science communication could well occur because of the Internet, which offers a novel opportunity for non-competitive groups inside organizations to challenge traditional approaches. This emerging knowledge system combines the advantages of human uniqueness and individuality with intelligent computer networks to quickly solve a syntactically complex problem (Johnson et al., 1998).

The single Brazilian publication to don the cover of Nature is not necessarily an indication that science in Brazil has attained a higher level of competence, even though Brazil publishes more biological journals than other nations of comparable dimensions, such as Australia, Canada and Russia, according to listings of the most productive countries in the world (Christoffersen, 1994). This more visible Brazilian production may represent the tip of the iceberg. We do not doubt our capacity to produce articles involving high technology or to question and modify important aspects of universal knowledge. After all, new and interesting ideas are not the privilege of a small group of nations or cultures. However, we must always give precedence to quality over quantity and impact of publications, creativity over visibility of scientists, inclusiveness over selectivity of indexed journals, and anonymous authorship for the reviewer rather than anonymous reviewers in the review process, if we are to avoid the vicious circle of the Matthews effect in science (Merton, 1988). The very cogwheels of science are becoming rather rusty and in need of lubrication. Let us enter a new era of non-competitive teamwork in science on a truly international scale. This integrated work should not be restricted to practical results that stress shortterm instrumental good, nor subjugated to technological transnational firms and organizations that bow to market interests, but should also extend to the search for scientific literacy in its broadest sense. Full scientific literacy emphasizes scientific ways of knowing and the process of thinking critically and creatively about our natural world. We should always stress long-term processes over short-term products and give priority to questions over answers (Maienschein, 1998).

\section{REFERENCES}

AARONSON, Steve.

The footnotes of science in acknowledging the work of others, authors tell a lot about science itself. Mosaic, Winnipeg, v.6, n.2, p.22-27. 1975.

BARNETT, Anthony; FULLER, Steve.

Dialogue reviews: science. Interdisciplinary Science Review, London, v.24, n.4, p.331-339. 1998.

BRANNIGAN, Augustine.

The reification of Gregor Mendel. Social Studies in Science, New York, v.9, p.423-454. 1979.
CHRISTOFFERSEN, Martin Lindsey.

A personal recipe for scientific fulfilment in normal environments. Ciência e Cultura, São Paulo, v.46, n.3, p.133-134. 1994.

CUNHA, Antônio Brito da.

Perspectivas atuais e futuras das ciências biológicas no Brasil. Brasília: CNPq. 1990.

DE MASI, Domenico.

O ócio criativo. 2 ed. Rio de Janeiro: Sextante. 2000 . 
GARDNER, Howard.

Creating minds: an anatomy of creativity seen through the lives of Freud, Einstein, Picasso, Stravinski, Eliot, Graham, and Ghandi. New York: Basic Books. 1996.

GARFIELD, Eugene.

More on forecasting Nobel prizes and the most cited scientists of 1972. Current Contents, Philadelphia, n.40, p.5-6, 1973a.

GARFIELD, Eugene.

The mythology of scientific information and doomsday philosophers. Current Contents, Philadelphia, n.25, p.5-6. 1973b.

GARFIELD, Eugene.

Publication counting vs. citation counting in evaluating research. Current Contents, Philadelphia, n.9, p.3. 1971.

GARFIELD, Eugene.

Citation measures used as an objective estimate of creativity. Current Contents, Philadelphia, n.26, p.2. 1970.

GHISELIN, Michael T.

Michael Ruse's Mystery of mysteries: is

evolution a social construction?. Isis,

Washington, v.91, n.2, p.374-375. 2000.

GRANTHAM, Todd.

Philosophical perspectives on the mass extinction debates? Biology \& Philosophy, Amsterdam, v.14, p.143-150, 1999.

HORGAN, John.

The end of science. New York: Broadway Books. 1997.

HULL, David Lee.

Science as a process. Chicago: University of Chicago Press. 1997.

JOHNSON, Norman Lloyd.

Importance of diversity: reconciling natural selection and non-competitive processes. Annals of the New York Academy of Science, New York, v.901, p.54-66. 2000.

JOHNSON, Norman Lloyd et al.

Symbiotic intelligence: self-organizing knowledge on distributed networks, driven by human interaction. California: Los Alamos. 1998.

KUHN, Thomas Samuel.

The structure of scientific revolutions. Chicago: University of Chicago Press. 1962.

MAIENSCHEIN, Jane.

Competing epistemologies and developmental biology. In: Creath, Richard; Maienschein, Jane
(Ed.). Biology and epistemology. Massachusetts: Cambridge University Press. p.122-137. 2000.

MAIENSCHEIN, Jane.

Scientific literacy. Science, Washington, v.281, p.917. 1998.

MERTON, Robert King.

The Matthew effect in science, II. Cumulative advantage and the symbolism of intellectual property. Isis, Washington, v.79, p.606-623. 1988.

OLIVEIRA, João Batista Araújo.

Ilhas de competência: carreiras científicas no Brasil. São Paulo: Brasiliense. 1985.

POPPER, Karl Raimund.

A racionalidade das revoluções científicas In: Harré, Ron (Ed.). Problemas da revolução científica. Belo Horizonte: Itatiaia. p.91-122. 1976.

PROLLA, Thomas.

When Brazilians achieve, it's against all the odds. Nature, London, n.406, p.826. 2000.

REISH, Donald.

An analysis of a sample of systematic literature, 1758 to 1954. Systematic Zoology, Lawrence, v.7, n.4, p.174-179. 1958.

SAIZ-SALINAS, José Ignácio.

Failed professor. Nature, London, n.381, p.4. 1996.

SALZANO, Francisco Mauro.

Genética e genômica: 135 anos de investigação científica. Pesquisa FAPESP, São Paulo, v.54, p.12-13. 2000.

SAPP, Jan.

The nine lives of Gregor Mendel. In: Le Grand, Homer Eugene (Ed). Experimental inquiries. Netherlands: Kluwer Academic Publishers. p.137-166. 1990.

SARDENBERG, Ronaldo.

Untitled text presented at the 52nd Annual Meeting of the Brazilian Society for the Progress of Science (SBPC), in Brasília, July 2000. Pesquisa FAPESP, São Paulo, n.54, p.25. 2000.

SIMPSON, Andrew John George et al. The genome sequence of the plant pathogen Xylella fastidiosa. Nature, London, n.406, p.151-157. 2000.

ZARUR, George de Cerqueira Leite. Schools and paradigms in Brazilian zoology. Interciencia, Caracas, v.19, n.4, p.183-190, 1994. 